\title{
Família, gênero e política nas eleições de municípios rurais no sudoeste da França
}

\author{
Mônica Helena Harrich Silva Goulart ${ }^{1}$
}

O artigo de Victor Marneur (2016), Le genre de l'hérédité em politique: une filière d'accès pour les élues municipales en Gironde? [O gênero da hereditariedade na política: uma via de acesso para os eleitos municipais da Gironda] $]^{2}$, apresenta informações relativas à sua pesquisa de doutorado ${ }^{3}$ em Ciência Política, investigação que está centralizada na discussão sobre gênero e poder local.

Conforme OLIVEIRA e GOULART (et al., 2017), a presença de famílias na ocupação de cargos políticos não se restringe à realidade brasileira, e tão menos se configura como um fenômeno latino-americano. Também não se constitui como fenômeno do passado, de sistemas políticos arcaicos, aspecto que se constitui a importância do texto de Marneur, uma vez que apresenta vasta bibliografia e estudos de caso sobre o tema a partir do contexto francês ${ }^{4}$.

Por meio dos apontamentos do autor sobre os municípios rurais da Gironda, pode-se direcionar uma série de reflexões fundamentais para pensarmos também acerca da realidade brasileira, sobretudo paranaense, no que tange à relação entre política, relações de parentesco e questões de gênero: i) a transmissão hereditária de mandatos políticos em regimes democráticos; ii) a capilaridade de municípios sob o domínio político e histórico de grupos familiares; iii) a importância da herança política para acesso ao poder político; iv) as dificuldades, limitações e presença das mulheres nos cargos políticos eletivos.

De forma específica, e levando em consideração os aspectos mencionados anteriormente, por meio da pesquisa desenvolvida entre os anos 2012 a 2014, Marneur destaca a maneira ocorrem as transmissões

\footnotetext{
${ }^{1}$ Professora Adjunta no Departamento Acadêmico de Estudos Sociais da UTFPR (Universidade Tecnológica Federal do Paraná) e Professora Colaboradora no Programa de Pós-Graduação em Sociologia da UFPR (Universidade Federal do Paraná). Contato: mharrich@uol.com.br.

2 Texto original "Le genre de l'hérédité en politique: une filière d'accès pour les élues municipales en Gironde?», Critique internationale, vol. 73, № 4, 2016, p. 53-70. Disponível em https://www.cairn.info/revue-critique-internationale-2016-4-page53.htm. Acesso 25.outubro.2017.

3 A presente tese se apresenta em andamento, no Centro Emile Durkheim, Borudeaux, sob a orientação de Marion Paoletti.

4 Vale conferir o artigo de Alexandre Niess (2012) que aponta os aspectos contraditórios nas relações entre hereditariedade política e República no contexto francês. Para o autor, as transmissões de poder político familiar cabem efetivamente às dimensões da Monarquia e não em cenários democráticos.
} 
hereditárias na política local (isto é, nos municípios rurais na região sudoeste da França, chamada de departamento da Gironda ${ }^{5}$.

Diante de tais transmissões, o autor enfatiza a situação das mulheres nesse processo na medida em que apresentam "limitações" para recebimento da herança política. Afinal, os exemplos estudados indicam que a transferência tende a privilegiar os filhos homens, notadamente os primogênitos, e é justamente nesta dificuldade/lacuna que as mulheres (dentro de certas condições) "acabam" recebendo o presente legado. Este fato é mencionado por Marneur e considerado em casos de "meninos faltantes". Assim, pontua por meio de seus estudos e entrevistas com vereadoras e prefeitas os mecanismos de transmissão de poder pontuando a seguinte questão: qual a probabilidade das mulheres herdarem estes cargos diante da natureza patrilinear das transmissões?

Em termos gerais, as "falas" das mulheres demonstram que a transmissão ocorre fundamentalmente por meio de linhagem familiar ${ }^{6}$ através de pais, esposos e até mesmo de sogros. Indivíduos estes que acumularam durante certo tempo cargos, prestígio e poder nos seus municípios, além de serem proprietários de terras, haja vista que o cenário da pesquisa ocorre em municípios rurais e, assim, o patrimônio territorial, ainda que restrito, acaba sendo fator estruturante para construção do patrimônio simbólico e obtenção de renome diante da arena política. Tanto os primogênitos homens quanto as mulheres podem obter os cargos a partir da hereditariedade política e da hereditariedade eletiva.

Neste caso, Marneur estabelece que a hereditariedade política se refere à socialização na política, ou seja, se coloca como uma espécie de predisposição para os assuntos da política, uma espécie de interesse aos aspectos públicos. Dessa forma, pode-se ter um parente com cargo político, porém não no mesmo município e em outro contexto histórico. Já a hereditariedade eletiva, considerada como transmissão do mandato, pressupõe ter um parente próximo que foi eleito no município, fato que permite a transferência quase que automática (e "mágica") aos mais jovens por pertencerem ao mesmo grupo familiar e isto ocorre também porque o prestígio do sobrenome o permite. Afinal, quanto mais tempo e cargos acumulados, maior presença e importância no meio político, ocasionando grandes chances para garantia do voto.

Contudo, a questão essencial apontada por Marneur é que mesmo diante de situações isoladas e seletivas, o fato de mulheres terem acesso a cargos políticos, ainda que recebidos por linhagem familiar e

\footnotetext{
${ }^{5} \mathrm{~A}$ Gironda corresponde a um dos vários departamentos metropolitanos que compõem a divisão político-administrativa da França. Este departamento abarca municípios do sudoeste da França, região chamada Nova Aquitânia, onde se encontram municípios como: Bordeaux, Mérignac, Arcachon, Pessac, entre outros.

6 Diante de significativas diferenças contextuais e nacionais, vale ressaltar que a análise da linhagem política se faz necessária em todos os estudos que almejam relacionar política e questões de gênero, pois permite compreender os mecanismos de entrada das mulheres na vida política. Como exemplo, temos o caso da Assembleia Legislativa do Paraná (ALEP), onde somente 21 mulheres tiveram acesso ao parlamento ao longo de mais de 120 anos. Dentre as parlamentares, 12 apresentaram parentes próximos (pai, filho, esposo e sogro) na política e uma décima terceira com parentes distantes. Em se tratando de esposos, nove mulheres tiveram transmissão de capital político por meio do prestígio do nome do marido, ressaltando a importância do matrimônio em termos de transmissão de capital política. (GOULART, 2016).
} 
transmitidos principalmente por homens, se apresenta como elemento fundamental porque promove a entrada e presença feminina nos espaços de poder. Assim, no referido caso francês, as transmissões hereditárias recebidas por mulheres em contextos locais (sobretudo em municípios com menos de 3.500 habitantes) e em regiões rurais, constitui-se como elemento positivo ao promover certa "ruptura" na arena política. Aspectos estes que se apresentam primordiais para reflexão em outras realidades sociais.

\section{Referências Bibliográficas}

GOULART, Mônica Helena Harrich Silva. As mulheres na ALEP: uma abordagem prosopográfica. In: OLIVEIRA, Ricardo Costa de. (org.). Nepotismo, Parentesco e Mulheres. 2. ed. Curitiba: Urbi et orbi, 2016.

MARNEUR, Victor. Le genre de l'hérédité em politique: une filière d'accès pour les élues municipales en Gironde? Critique internationale, v.4, n.73, p. 53-70, oct-dec. 2016.

NIESS, Alexandre. Carreiras políticas e nepotismo na Terceira República francesa (1871-1940). Revista Brasileira de Ciência Política, Brasília, n.8, maio-ago. 2012.

OLIVEIRA, Ricardo Costa de; GOULART, Mônica Helena Harrich Silva; VANALI, Ana C.; MONTEIRO, José Marciano. Família, parentesco, instituições e poder no Brasil: retomada e atualização de uma agenda de pesquisa. Revista Brasileira de Sociologia, v.5, n. 11, p. 165-198, set.-dez. 2017. 